Abstracta Iranica Abstracta Iranica

Revue bibliographique pour le domaine irano-aryen

Volume 25 | 2004

Comptes rendus des publications de 2002

\title{
Asb nāme-hā-ye fārsī. Tehrān, Sāzmān-e Mīrāte-e Farhangì-ye Kešvar, 1379 [2001], 131 p.
}

Jean-Pierre Digard

\section{OpenEdition}

1 Journals

Édition électronique

URL : http://journals.openedition.org/abstractairanica/5241

DOI : 10.4000/abstractairanica. 5241

ISSN : 1961-960X

\section{Éditeur :}

CNRS (UMR 7528 Mondes iraniens et indiens), Éditions de l'IFRI

\section{Édition imprimée}

Date de publication : 15 mai 2004

ISSN : 0240-8910

\section{Référence électronique}

Jean-Pierre Digard, « Asb nāme-hā-ye fārsī. Tehrān, Sāzmān-e Mīrāț-e Farhangī-ye Kešvar, 1379 [2001], 131 p. », Abstracta Iranica [En ligne], Volume 25 | 2004, document 360, mis en ligne le 15 mars 2006 , consulté le 25 septembre 2020. URL : http://journals.openedition.org/abstractairanica/5241 ; DOI : https://doi.org/10.4000/abstractairanica.5241

Ce document a été généré automatiquement le 25 septembre 2020.

Tous droits réservés 


\section{Asb nāme-hā-ye fārsī. Tehrān, Sāzmān-e Mīrāte Farhangī-ye Kešvar, 1379 [2001], 131 p.}

Jean-Pierre Digard

1 Recueil de 55 notices descriptives de traités d'équitation et d'hippologie écrits ou traduits en persan, de l'Antiquité au $19^{\mathrm{e}} \mathrm{s}$., se trouvant dans les bibliothèques iraniennes. Les notices sont inégales : les plus développées comportent une biographie de l'auteur et une description du contenu de l'ouvrage, les plus courtes - quelques lignes - se contentent d'indiquer le lieu de conservation de l'ouvrage.

INDEX

Thèmes : 16.1. Iran

\section{AUTEURS}

JEAN-PIERRE DIGARD

CNRS - Paris 